Article

\title{
Improving Biodiesel Conversions from Blends of High- and Low-Acid-Value Waste Cooking Oils Using Sodium Methoxide as a Catalyst Based on a High Speed Homogenizer
}

\author{
Ming-Chien Hsiao ${ }^{1,2}$, Jui-Yang Kuo ${ }^{1}$, Pei-Hsuan Hsieh ${ }^{3}$ and Shuhn-Shyurng Hou ${ }^{2,4, * \text { (D) }}$ \\ 1 Department of Environmental Engineering, Kun Shan University, Tainan 71070, Taiwan; \\ johnson@mail.ksu.edu.tw (M.-C.H.); dbormana@gmail.com (J.-Y.K.) \\ 2 Green Energy Technology Research Center, Kun Shan University, Tainan 71070, Taiwan \\ 3 Department of Materials Science and Engineering, National Tsing Hua University, Hsinchu 30013, Taiwan; \\ s105031532@m105.nthu.edu.tw \\ 4 Department of Mechanical Engineering, Kun Shan University, Tainan 71070, Taiwan \\ * Correspondence: sshou@mail.ksu.edu.tw; Tel.: +886-6-205-0496
}

Received: 3 August 2018; Accepted: 29 August 2018; Published: 31 August 2018

\begin{abstract}
Biodiesel is an environmentally friendly and sustainable fuel. However, the high price of the biodiesel produced from pure vegetable oil contributes to making it uncompetitive in the market. If we can make low cost oils such as waste cooking oil and high-acid-value oil available as resources, the cost of biodiesel production will be reduced significantly. However, these low cost oils cannot be used to produce biodiesel directly because they usually contain a large amount of free fatty acids. They have to undergo a preparatory procedure to lower the acid value to a specific value. The purpose of this study was to lower the amount of free fatty acids in waste cooking oils by blending high- and low-value oils at different ratios and to reduce the transesterification reaction time using a high speed homogenizer, which has the potential to easily enlarge the capacity scale. We used a high-acid-value oil to low-acid-value oil volume ratio of 4:6 as a control. A high conversion rate $(97.1 \%)$ was achieved under the optimal reaction conditions: methanol-to-oil molar ratio, 9:1; amount of catalyst $\left(\mathrm{CH}_{3} \mathrm{ONa}\right)$ used, $0.75 \mathrm{wt} \%$; reaction temperature, $65^{\circ} \mathrm{C}$; rotation speed, $8000 \mathrm{rpm}$; and reaction time, $8 \mathrm{~min}$.
\end{abstract}

Keywords: biodiesel; transesterification; waste cooking oil; homogenizer; sodium methoxide

\section{Introduction}

The increasing demand for energy and the awareness of dangerous environmental pollution have existed since the industrial revolution in the 1800s. Scientists are now continuously seeking alternative sources of renewable energy [1]. The development of biodiesel is being driven by the need to slow down the depletion of fossil fuels and reduce gas emissions into the air. Biodiesel can be produced from animal fats or vegetable oils with methanol or ethanol as the catalyst via a transesterification reaction. Biodiesel can be defined as a monoalkyl ester of long chain fatty acids [2] derived from a renewable lipid source. It is a new alternative to fossil fuels. Compared to the transportation of oil from fossil fuels, biodiesel's delivery is much safer and less volatile. It can directly replace diesel oil for any mechanical equipment and can be restored in any storage facility designed for oil. Biodiesel oil has unique advantages, including renewability and biodegradability and the fact that it is eco-friendly [3] and non-toxic to nature [4]. 
The major hurdle for the biodiesel oil commercialization is its high cost, which is approximately two times higher than that of fossil fuels due to the cost of vegetable oil $[5,6]$. Producing biodiesel oils from waste cooking oil would greatly lower the costs and efficiently solve the problem of waste oil disposal [5,7-12] at the same time. Researchers have shown that using waste cooking oil as a raw material to produce biodiesel oil can reduce emissions of PM, hydrocarbons (HCs), carbon monoxide (CO), and sulfur dioxide $\left(\mathrm{SO}_{2}\right)$ from generators and the emissions of polycyclic aromatic hydrocarbons (PAHs) from engines [13-15], with a slight increase in the emissions of nitrogen oxide (NOx) [16,17]. This problem can be ameliorated by adjusting the diesel injector [18-22].

Another way to reduce biodiesel production costs is to find the optimal parameters, including reaction temperature, reaction time, the amount of the catalyst to be added in the reaction, and the methanol-to-oil ratio. Some researchers have experimented with base catalytic reactions, acid catalytic reactions, and enzymatic transesterification and have found that a base-catalytic reaction obtained the best result. Biodiesel can be produced under a lower temperature with a base catalyst, whereas a transesterification reaction with an acid catalyst requires higher temperatures and a longer reaction time [23,24]. Ganesh et al. [25] studied ultrasound-assisted transesterification of waste cooking oil using potassium methoxide as a base catalyst. Under the optimal condition, the conversion rate of biodiesel oil could reach $90 \%$ in $30 \mathrm{~min}$. Compared with conventional stirring, which requires 1-3 h, a reaction under ultrasound has been shown to significantly raise the efficiency of biodiesel production.

In previous research, Chen et al. [26] carried out experiments using a microwave heating system. Sodium methoxide was used as a base catalyst. The optimal reaction condition was $0.75 \mathrm{wt} \% \mathrm{CH}_{3} \mathrm{ONa}$ catalyst, a methanol-to-oil molar ratio of $6: 1$, and a reaction time of $3 \mathrm{~min}$. In the present study, we carried out experiments under a homogenizer system instead of a microwave heating system. A homogenizer is widely applied in dairy-related industries for the preparation of coarse pre-emulsions because it promotes emulsification and homogenization effectively. Researchers have reported that esterification with high-shear blenders and mixing with a homogenizer is more efficient than the use of conventional stirring. In industrialization processes, it not only saves time and effort but is also low-cost $[27,28]$. However, at present, researchers have not done many studies on the transesterification of biodiesel using a homogenizer system.

Recently, Mohod et al. [29] investigated the production of biodiesel using waste cooking oil and fresh cooking oil as biodiesel feedstocks based on the use of a high speed homogenizer. It was reported that the maximum yield of biodiesel was $97 \%$ for waste cooking oil and $92.3 \%$ for fresh cooking oil under optimized operating conditions: a catalyst loading $(\mathrm{KOH})$ of $3 \mathrm{wt} \%$, a methanol-to-oil molar ratio of $12: 1$, an operating temperature of $50{ }^{\circ} \mathrm{C}$, and a reaction time of $120 \mathrm{~min}$. The study demonstrated that the application of cavitation caused by a homogenizer provides the advantages of a transesterification reaction with reduced reaction time and enhanced separation. However, the effect of rotation speed was not investigated. Joshi et al. [30] also used a homogenizer to explore the intensification of biodiesel production from soybean oil and waste cooking oil. It was found that the highest yield of biodiesel was $84 \%$ for soybean oil under the optimal reaction conditions: a catalyst $(\mathrm{CaO})$ loading of $3 \mathrm{wt} \%$, a methanol-to-oil molar ratio of 10:1, a reaction temperature of $50{ }^{\circ} \mathrm{C}$, a rotation speed of $12,000 \mathrm{rpm}$, and a reaction time of $30 \mathrm{~min}$. With the exception that the catalyst loading was $1 \mathrm{wt} \%$, under the same optimal operating conditions as the soybean oil-produced biodiesel, the highest yield of biodiesel synthesized from waste cooking oil was $88 \%$. As compared to the conventional stirring method, the use of a high speed homogenizer could efficiently reduce the time and energy required to produce biodiesel.

Research on the transesterification of biodiesel using a homogenizer system is relatively rare. The objective of this study was to promote a waste cooking oil transesterification reaction by using a homogenizer with sodium methoxide catalyst to enhance the efficiency of biodiesel production. We examined how a homogenizer system influences the transesterification reaction with blending oils and determined the optimal conditions for the highest conversion by adjusting the catalyst loading, reaction time, reaction temperature, methanol-to-oil molar ratio, and rotation speed. 


\section{Experiments}

\subsection{Experimental Setup and Transesterification Procedure}

Sodium hydroxide (NaOH; purity: 98\%) was purchased from Mallinckrodt. Methanol $\left(\mathrm{CH}_{3} \mathrm{OH}\right.$; purity: 99.8\%) was obtained from Shiyaku. Methyl laurate and acetic acid were purchased from Fluka. Sodium methylate $\left(\mathrm{CH}_{3} \mathrm{ONa}\right)$ was obtained from Alfa Aesar. The $\mathrm{NaOH}$, methanol and $\mathrm{CH}_{3} \mathrm{ONa}_{\text {were }}$ high-performance liquid chromatography (HPLC) grade. Waste cooking oil was collected from local restaurants in Tainan City, Taiwan.

The experimental setup is shown in Figure 1. A homogenizer synthesis reactor (Hsiangtai H-M-300, Hsiangtai Co., Ltd., New Taipei City, Taiwan) is equipped with a thermostatic tank and a condenser used for homogenizer reactions. The experiments were carried out at two different catalysts $\left(\mathrm{CH}_{3} \mathrm{ONa}\right.$ and $\left.\mathrm{NaOH}\right)$ with different ratios based on the weight of waste cooking oil, various methanol-to-oil molar ratios (7:1, 8:1, 9:1, 10:1 and 11:1), reaction times ranging 4-12 min, and rotation speeds of 5000, 6000, 7000, 8000, and 9000 rpm. A conventional heating system (HTS-1003, Harmony, Japan) equipped with a mechanical stirrer and a condenser (LC-10, Hi-point Co., Ltd., Kaohsiung City, Taiwan) was used for the conventional heating reactions.

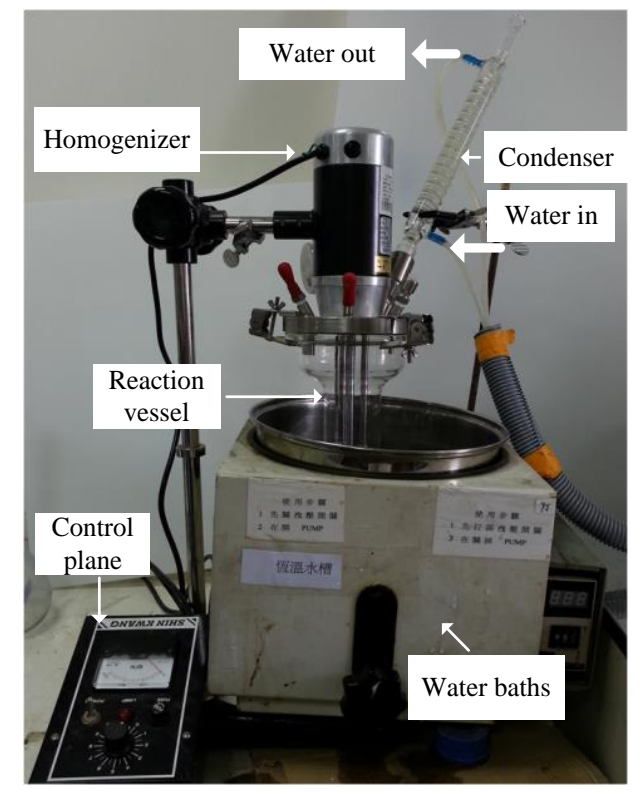

Figure 1. The experimental setup.

\subsection{Analytical Methods}

The acid value (AV) and saponification value (SV) were determined in accordance with the official methods set forth by the AOCS (America Oil Chemists' Society). That is, the acid value was assessed using AOCS Official Method Cd 3d-63 [31], and the saponification value was determined with AOCS Official Method Cd 3-25 [32]. The acid value was measured as follows: $5.0 \mathrm{~g}$ of the oil was added into a $150 \mathrm{~mL}$ alcohol/ether $(1: 1 ; v / v)$ solution in a $250 \mathrm{~mL}$ Erlenmeyer flask; then, a small amount of 1\% phenolphthalein indicator was added into the solution. Eventually, we titrated with a $0.1 \mathrm{~N}$ potassium hydroxide solution. The saponification value was measured as follows: $2.0 \mathrm{~g}$ of the oil was added into a $25 \mathrm{~mL}$ potassium hydroxide/alcohol $(1: 1 ; v / v)$ solution in a $250 \mathrm{~mL}$ Erlenmeyer flask. The solution was refluxed with heat for one hour. Then, a few drops of $1 \%$ phenolphthalein indicator was added into the solution. Eventually, we titrated with $0.5 \mathrm{~N}$ hydrochloric acid.

The acid value (AV) of the waste cooking oil was calculated according to the following equation: 


$$
\mathrm{AV}=\frac{5.61 \times \mathrm{V}_{\mathrm{NaOH}}}{\mathrm{W}}
$$

where $\mathrm{V}_{\mathrm{NaOH}}$ is the volume of sodium hydroxide titrant used $(\mathrm{mL})$, and $\mathrm{W}$ is the oil weight $(\mathrm{g})$.

The saponification value (SV) of the waste cooking oil was calculated with the formula below:

$$
\mathrm{SV}=\frac{(\mathrm{B}-\mathrm{S}) \times 56.1 \times 0.5}{\mathrm{~W}}
$$

where $\mathrm{S}$ is sample titration amount $(\mathrm{mL})$, B is blank titration amount $(\mathrm{mL})$, and $\mathrm{W}$ is oil weight $(\mathrm{g})$.

The molecular weight (MW) of the waste cooking oil (WCO) was calculated using Equation (3) from its saponification value and acid value [33], and is given in Table 1.

$$
\mathrm{MW}=56.1 \times 1000 \times \frac{3}{(\mathrm{SV}-\mathrm{AV})}
$$

where $\mathrm{SV}$ is the saponification value ( $\mathrm{mg} \mathrm{KOH} / \mathrm{g}$ ) and $\mathrm{AV}$ is the acid value (mg $\mathrm{KOH} / \mathrm{g}$ ).

Table 1. Properties of high-acid-value WCO and low-acid-value WCO.

\begin{tabular}{cccc}
\hline WCO Type & AV (mg KOH/g) & SV (mg KOH/g) & MW \\
\hline High-acid-value WCO & 4.812 & 220.613 & 779.89 \\
Low-acid-value WCO & 0.062 & 223.558 & 753.03 \\
\hline
\end{tabular}

Note: $\mathrm{WCO}$, waste cooking oil; $\mathrm{AV}$, acid value; $\mathrm{SV}$, saponification value; $\mathrm{MW}$, molecular weight.

In the present study, the analytical method used to determine the content of FAME followed the Taiwan CNS-15051 standard. Many studies follow the CNS-15051 standard (e.g., Chen et al. [26] and Kuan et al. [34]). The biodiesel samples were analyzed with a Perkin Elmer GC Clarus 600 equipped with a capillary column (SPBTM-WAX, $30 \mathrm{~m} \times 0.75 \mathrm{~m} \times 1.0 \mu \mathrm{m}$ ) and a flame ionization detector (FID). The FAME standards for GC calibration were methyl laurate (C12:0 used as the internal standard [35-37]), methyl myristate (C14:0), methyl palmitate (C16:0), methyl palmitoleate (C16:1), methyl stearate (C18:0), methyl oleate (C18:1), methyl linoleate (C18:2), and methyl linolenate (C18:3). Their retention times thus were employed in identifying the chromatogram images obtained from the biodiesel samples.

In this study, $0.05 \mathrm{~g}$ of methyl laurate and $10 \mathrm{~mL}$ of hexane were added as internal standards into crude biodiesel $[35,36]$. Then, $0.5 \mathrm{~g}$ of the sample was mixed evenly with internal standards and a small portion of the sample $(1 \mu \mathrm{L})$ was injected under the following conditions: the injector temperature was $280{ }^{\circ} \mathrm{C}$ with a split ratio of 1:20, the carrier gas was nitrogen at a flow rate of $45 \mathrm{~mL} \mathrm{~min}^{-1}$, the airflow rate was $450 \mathrm{~mL} \mathrm{~min}^{-1}$, and the temperature of the detector was $300{ }^{\circ} \mathrm{C}$. Oven temperatures were started at $210{ }^{\circ} \mathrm{C}$, held for $4 \mathrm{~min}$, increased to $240{ }^{\circ} \mathrm{C}$ at a rate of $4{ }^{\circ} \mathrm{C} \mathrm{min}{ }^{-1}$, and held there for $8 \mathrm{~min}$.

After the FAME area (sum of peak FAME area from C14 to C24:1) and area of reference (peak area of the internal standard) were calculated, then the conversion rate of biodiesel could be obtained using Equation (4) $[35,36]$ :

$$
\text { Conversion }(\%)=\frac{\left(\frac{\text { area of FAME }}{\text { area of reference }}\right) \times \text { weight of reference }}{\text { weight of crude oil }}
$$

The data on conversion rate were obtained by averaging three individual measurements and the standard deviations were shown with error bars. 


\section{Results and Discussion}

\subsection{The Best Ratio of the High-Acid-Value Oil to Low-Acid-Value Oil}

The acid value (AV), saponification value (SV), and molecular weight (MW) of the high-acid-value oil and low-acid-value oil were analyzed, as shown in Table 1. The large amount of free fatty acids (FFAs) in high-acid-value oil causes the oil to hydrolyze and oxidize more easily. Therefore, we blended high-acid-value oil with low-acid-value oil to balance the free fatty acids instead of pre-producing the high-acid-value oil into suitable oil for the experiment using acid and base catalysts. Canakci and Van Gerpen [38] treated feedstock with $\mathrm{H}_{2} \mathrm{SO}_{4}$ to reduce the level of free fatty acids to below 1 wt \%, followed by a transesterification reaction catalyzed by homogeneous base $\mathrm{KOH}$. This two-step process for the acid catalyzed esterification process and base catalyzed transesterification process were used to produce biodiesel from $C$. inophyllum oil with high FFA. The drawback of this two-step process is the requirement of extra steps to separate the catalysts from the products and the increased time necessary to remove the catalyst in both stages. In addition, the use of an extra catalyst will add to the cost of biodiesel production. Moreover, it requires more water to clean the catalysts. It was shown in previous research that an $\mathrm{AV}$ lower than $2 \mathrm{KOH} \mathrm{mg/g}$ facilitates the transesterification reaction of biodiesel [39]. Thus, if oil contains higher amounts of FFAs ( $>2 \mathrm{KOH} \mathrm{mg/g),} \mathrm{it} \mathrm{will} \mathrm{form} \mathrm{soap} \mathrm{with} \mathrm{the} \mathrm{use} \mathrm{of} \mathrm{an}$ alkaline catalyst (Scheme 1).

$$
\begin{aligned}
& \mathrm{RCOOH}+\mathrm{NaOH} \rightarrow \mathrm{RCOONa}+\mathrm{H}_{2} \mathrm{O} \\
& \text { FFAs } \quad \text { Soap }
\end{aligned}
$$

(Scheme 1)

The AVs of blended oil are shown in Table 2. In our research, high-acid-value oil and low-acid-value oil were blended in different volume ratios to make the AV lower than $2 \mathrm{KOH} \mathrm{mg} / \mathrm{g}$, causing the transesterification reaction was accomplished in one step. It was found that the best ratio of the high-acid-value oil to low-acid-value oil was $4: 6$, which was adopted for the experiments.

Table 2. The acid values of blends of high- and low-acid-value waste cooking oils at different mixing ratios.

\begin{tabular}{lllllll}
\hline HA:LA & $10: 0$ & $8: 2$ & $6: 4$ & $4: 6$ & $2: 8$ & $0: 10$ \\
Acid Value & 4.18 & 3.23 & 2.08 & 1.98 & 1.02 & 0.54 \\
\hline \multicolumn{7}{c}{ Note: HA, high-acid-value WCO; LA, low-acid-value WCO. }
\end{tabular}

\subsection{Comparison of the Conversion for Homogenizer and Conventional Heating}

A comparison of the conversion with the $\mathrm{NaOH}$ catalyst between heating with a water bath (conventional heating) and heating with a homogenizer is shown in Table 3. The reaction was conducted with a methanol-to-oil molar ratio of 9:1, a $0.75 \mathrm{wt} \% \mathrm{NaOH}$ catalyst, a reaction time of $8 \mathrm{~min}$, and a reaction temperature of $65^{\circ} \mathrm{C}$. Table 3 shows that, at both 5 and $10 \mathrm{~min}$, the conversion was more significant by using the homogenizer for the process. Under the conventional heating system, the conversions were $5.04 \%$ and $9.66 \%$ at $5 \mathrm{~min}$ and $10 \mathrm{~min}$, respectively, while, under the homogenizer system, the conversions were $79.50 \%$ and $98.24 \%$ at $5 \mathrm{~min}$ and $10 \mathrm{~min}$, respectively. Specifically, the conversions with a homogenizer were 10 times higher than those with conventional heating at the same reaction time. The liquid was driven into a narrow shear zone because of the high rotor speed. The liquid was disseminated into small particles and distributed evenly. During the transesterification reaction, the reaction occurred in both the surface and in the interior. The heat was conducted to the surface of the heated objects and then gradually spread into the interior to raise the temperature of the core using conventional heating. This took a much longer than it did using a homogenizer to conduct the heat uniformly. In addition, the methanol was heated due to the friction generated by using a homogenizer. This promotes the rate of the reaction. We thus found that the reaction was processed more efficiently with the use of a homogenizer system. 
Table 3. Influence of conventional heating (water bath) and homogenizer on conversion rate.

\begin{tabular}{ccc}
\hline Method & Reaction Time (min) & Conversion (\%) \\
\hline Conventional water bath & 5 & 5.04 \\
Conventional water bath & 10 & 9.66 \\
Homogenizer & 5 & 79.50 \\
Homogenizer & 10 & 98.24 \\
\hline
\end{tabular}

Note: Operating conditions: a methanol-to-oil molar ratio of 9 , a $0.75 \mathrm{wt} \%$ catalyst $(\mathrm{NaOH})$, a reaction time of $8 \mathrm{~min}$, and a reaction temperature of $65^{\circ} \mathrm{C}$.

\subsection{Effects of Catalysts Type and Amounts of Catalysts}

Figure 2 shows the effects of catalyst type $\left(\mathrm{NaOH}\right.$ and $\left.\mathrm{CH}_{3} \mathrm{ONa}\right)$ and amounts of catalysts $(0.50 \%$, $0.75 \%, 1.00 \%, 1.25 \%$ and $1.50 \%$ by oil weight) on the conversion with a methanol-to-oil molar ratio of 9:1, a reaction temperature of $65^{\circ} \mathrm{C}$, a reaction time of $8 \mathrm{~min}$, and a rotation speed of $7000 \mathrm{rpm}$. It can be clearly seen that the conversions of biodiesel under $\mathrm{CH}_{3} \mathrm{ONa}$ catalyst were higher than those under $\mathrm{NaOH}$ catalyst. The conversion of biodiesel increased with the amount of the catalysts ranging from 0.50 to $1.00 \mathrm{wt} \%$, but then decreased in the range from 1.00 to $1.50 \mathrm{wt} \%$. The best conversion of biodiesel made from waste cooking oil was achieved with a $1.00 \mathrm{wt} \% \mathrm{CH}_{3} \mathrm{ONa}$ catalyst. When the $\mathrm{CH}_{3} \mathrm{ONa}$ catalyst was $0.75 \mathrm{wt} \%$, the conversion had already reached over $96.5 \%$ and thus complied with the Taiwan CNS 15072 biodiesel standard (96.5\%). Under this condition, excessive water would not be produced, and the product would reach a maximum yield. The transesterification reaction of the methanol and $\mathrm{NaOH}$ is based on Scheme 2 .

$$
\begin{gathered}
\mathrm{NaOH}+\mathrm{CH}_{3} \mathrm{OH} \rightarrow \mathrm{H}_{2} \mathrm{O}+\mathrm{Na}^{+}+\mathrm{CH}_{3} \mathrm{O}^{-} \\
\mathrm{CH}_{3} \mathrm{O}^{-}+\mathrm{H}_{2} \mathrm{O} \leftrightarrow \mathrm{CH}_{3} \mathrm{OH}+\mathrm{OH}^{-}
\end{gathered}
$$

(Scheme 2)

For base-catalyzed transesterification, glycerides and alcohol must be anhydrous because water will give rise to oil saponification, which increases viscosity [40,41]. In the experiments, we found that, when the catalysts over $2.1 \mathrm{wt} \%$ were added, the biodiesel led to the formation of soaps. When the catalyst was insufficient, it took a longer time to react and the biodiesel conversion was also lower. However, a further increase in the catalyst did not increase the conversion but rather decreased it. Similar results were also reported by Encinar et al. [41]. In this study, it was found that the most suitable catalyst loading was $0.75 \mathrm{wt} \%$ and that the conversions of biodiesel with the $\mathrm{CH}_{3} \mathrm{ONa}$ catalyst were higher than those with the $\mathrm{NaOH}$ catalyst.

\subsection{Effects of Methanol-to-Oil Molar Ratio}

According to the results discussed in Section 3.2, the transesterification reaction with the $\mathrm{CH}_{3} \mathrm{ONa}$ catalyst exhibited better conversion than that with the $\mathrm{NaOH}$ catalyst. Thus, $\mathrm{CH}_{3} \mathrm{ONa}$ was used as the catalyst in the remaining experiments. Experiments were carried out with a $0.75 \mathrm{wt} \% \mathrm{CH}_{3} \mathrm{ONa}$ catalyst, at a reaction temperature of $65^{\circ} \mathrm{C}$, a reaction time of $8 \mathrm{~min}$, a rotation speed of $7000 \mathrm{rpm}$, and various methanol-to-oil molar ratios (7:1, 8:1, 9:1, 10:1, and 11:1) to investigate the influence of the methanol-to-oil molar ratio on conversion. As shown in Figure 3, the conversion of biodiesel increased with increases in the methanol-to-oil molar ratio. The conversion was only $75.88 \%$ when the methanol-to-oil molar ratio was 7:1, due to the incomplete reaction. As the methanol-to-oil molar ratio increased from 7:1 to $9: 1$, the conversion increased from 75.8 to $96.7 \%$, ensuring adherence to the Taiwan CNS 15072 biodiesel standard (96.5\%). Furthermore, we obtained the best conversion of $97.38 \%$ when the methanol-to-oil molar ratio was 10:1. However, the conversion slightly decreased when the methanol-to-oil molar ratio was 11:1. This was attributed to the excess amount of methanol. The concentration of the catalyst was diluted when methanol was added excessively, causing a reverse reaction to occur. Furthermore, glycerol and biodiesel are miscible due to the use of excess methanol. 
The reaction could not be carried out efficiently, and therefore the conversion was lower [35]. From this experiment, we considered a methanol-to-oil molar ratio of 9:1 to be the most suitable level in terms of both conversion and production costs.

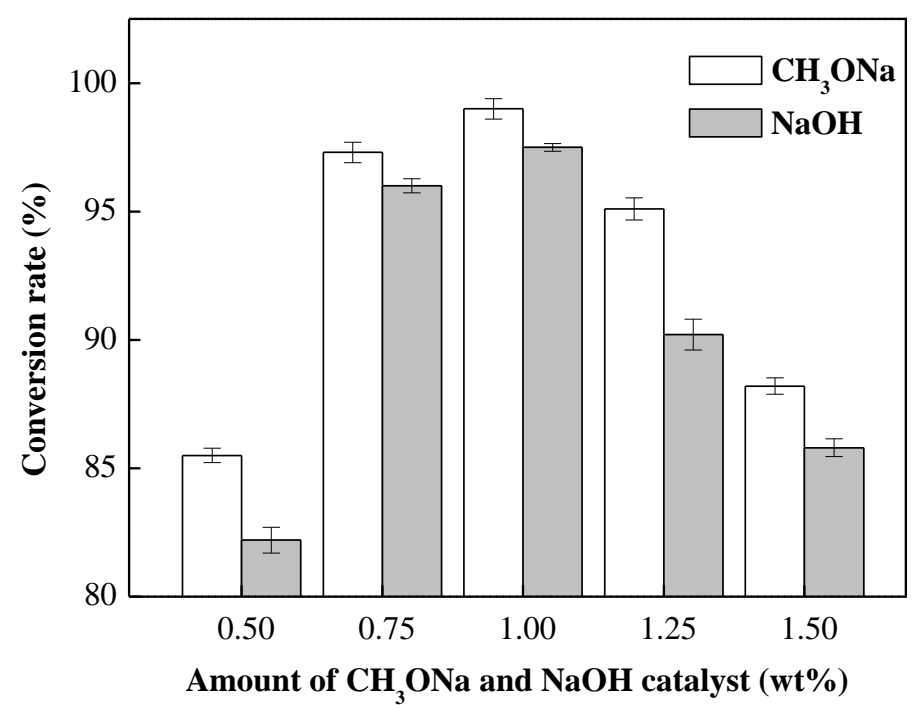

Figure 2. Effects of catalysts type and amounts of catalysts on the transesterification reaction. Reaction conditions: methanol-to-oil molar ratio, 9:1; amount of catalyst used, 0.5-1.5 wt \%; rotation speed, $7000 \mathrm{rpm}$; reaction temperature, $65^{\circ} \mathrm{C}$; and reaction time, $8 \mathrm{~min}$.

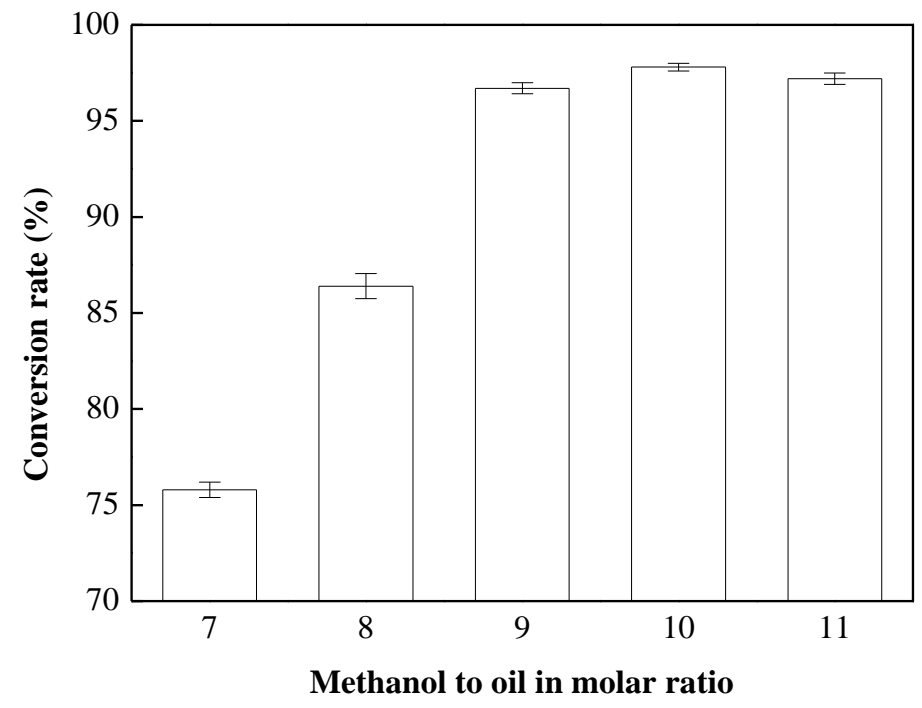

Figure 3. Effects of methanol-to-oil molar ratio on the transesterification reaction. Reaction conditions: methanol-to-oil molar ratio, 7:1-11:1; amount of catalyst used, $0.75 \mathrm{wt} \%$; rotation speed, $7000 \mathrm{rpm}$; reaction temperature, $65^{\circ} \mathrm{C}$; and reaction time, $8 \mathrm{~min}$.

\subsection{Effects of Rotation Speed}

Experiments were conducted with a $0.75 \mathrm{wt} \% \mathrm{CH}_{3} \mathrm{ONa}$ catalyst, at a reaction temperature of $65^{\circ} \mathrm{C}$, a reaction time of $8 \mathrm{~min}$, a methanol-to-oil molar ratio of 9:1, and various rotation speeds $(5000,6000$, 7000,8000 , and $9000 \mathrm{rpm}$ ) to investigate the influence of rotation speed on conversion. As illustrated in Figure 4, the conversion rate increased with increases in the rotation speed. The conversion rate was $98.3 \%$ when the rotation speed was $9000 \mathrm{rpm}$. Due to the increase in the rotation speed, the oil, methanol and catalysts mixed more homogeneously, and the contact surface area was also 
increased. Therefore, the conversion of biodiesel was enhanced to a higher level. To reduce the energy consumption and ensure adherence to the Taiwan CNS 15072 biodiesel standard, a rotation speed of $8000 \mathrm{rpm}$ was considered to be the most suitable speed in our study.

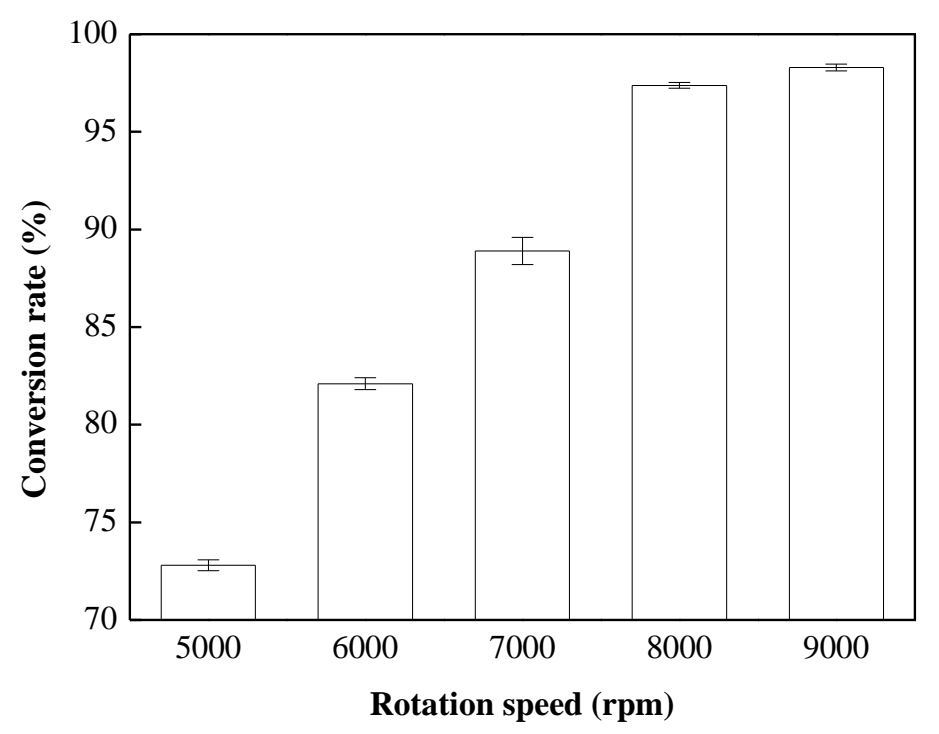

Figure 4. Effects of rotation speed on the transesterification reaction. Reaction conditions: methanol-to-oil molar ratio, 9:1, amount of catalyst used, $0.75 \mathrm{wt} \%$; rotation speed, 5000-9000 rpm; reaction temperature, $65^{\circ} \mathrm{C}$; and reaction time, $8 \mathrm{~min}$.

\subsection{Effects of Reaction Time and Reaction Temperature}

Experiments were carried out with a methanol-to-oil molar ratio of 9:1, a $0.75 \mathrm{wt} \% \mathrm{CH}_{3} \mathrm{ONa}$ catalyst, a rotation speed of $8000 \mathrm{rpm}$, various reaction temperatures $\left(55,60\right.$, and $\left.65{ }^{\circ} \mathrm{C}\right)$, and various reaction times $(4,6,8,10$, and $12 \mathrm{~min})$ to investigate the influence of reaction time and reaction temperature on conversion. As shown in Figure 5, an increase in reaction time from 4 to 10 min caused a significant increase in conversion, but the conversion decreased with a further increase in reaction time to $12 \mathrm{~min}$. Figure 5 also shows that temperature enhanced the conversion of biodiesel. Due to the lower temperature at $60{ }^{\circ} \mathrm{C}$, the conversion of biodiesel did not reach the standard (96.5\%) in 8 min but reached $97.1 \%$ in $10 \mathrm{~min}$. At $65^{\circ} \mathrm{C}$, the conversion reached $97.1 \%$, ensuring adherence to the Taiwan CNS 15072 biodiesel standard (96.5\%), in $8 \mathrm{~min}$. At $65{ }^{\circ} \mathrm{C}$, the system became disturbed because the temperature had reached the boiling point of methanol. When the reaction time went further to $10 \mathrm{~min}$ at a temperature of $65{ }^{\circ} \mathrm{C}$, the conversion slightly increased to $98.2 \%$, and the trend leveled steadily. However, with a further increase in reaction time from 10 to $12 \mathrm{~min}$, the conversion of biodiesel did not increase. The longer the reaction time was, the more the methanol turned into vapor. This caused the reaction to fail to enhance the conversion. Thus, excess reaction time did not enhance the conversion rate of biodiesel. 


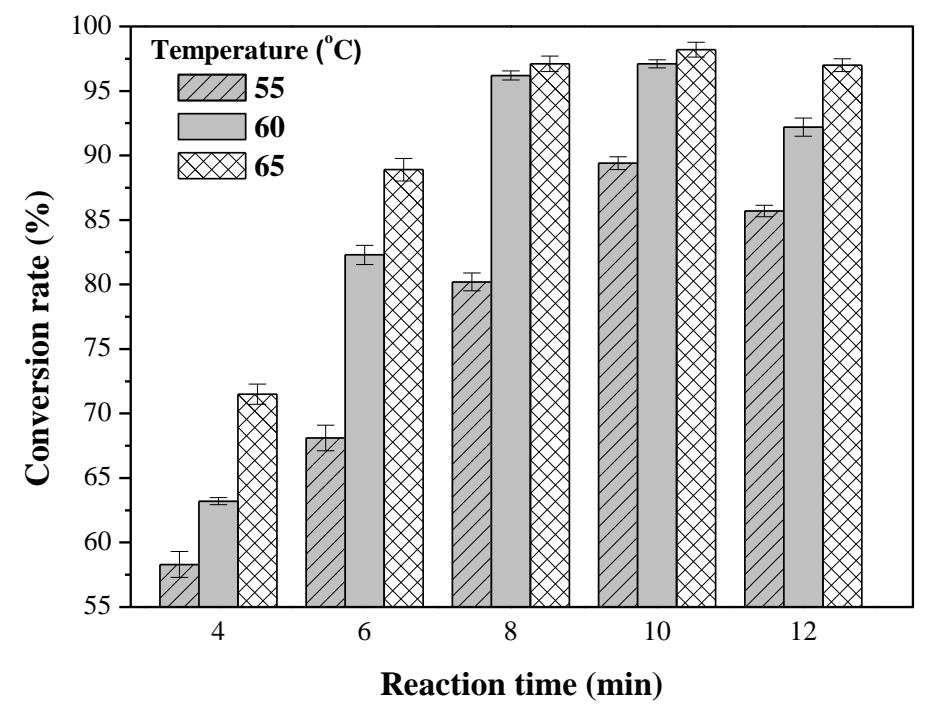

Figure 5. Effects of reaction time and reaction temperature on the transesterification reaction. Reaction conditions: methanol-to-oil molar ratio, 9:1; amount of catalyst used, $0.75 \mathrm{wt} \%$; rotation speed, $8000 \mathrm{rpm}$; reaction temperatures, 55,60 and $65^{\circ} \mathrm{C}$; and reaction time, 4-12 $\mathrm{min}$.

\section{Conclusions}

The experimental results show that the best ratio of the high-acid-value oil to low-acid-value oil was $4: 6$ to make the Acid value lower than $2 \mathrm{KOH} \mathrm{mg} / \mathrm{g}$ to complete the transesterification reaction in one step. The reaction time was reduced significantly and the conversion rapidly ensured adherence to the Taiwan CNS 15072 biodiesel standard (96.5\%) by using a high-speed homogenizer. Specifically, the conversions with a homogenizer were 10 times higher than those with conventional water bath heating at the same reaction time. Moreover, the conversions of the biodiesel using $\mathrm{CH}_{3} \mathrm{ONa}$ as a catalyst were higher than those with $\mathrm{NaOH}$ catalyst. It is noteworthy that a high conversion rate (97.1\%) was achieved under the optimal conditions: a methanol-to-oil molar ratio of $9,0.75 \mathrm{wt} \%$ $\mathrm{CH}_{3} \mathrm{ONa}$, a reaction temperature of $65^{\circ} \mathrm{C}$, and a rotation speed of $8000 \mathrm{rpm}$ for $8 \mathrm{~min}$.

Author Contributions: J.-Y.K. and P.-H.H. performed the experiments and analyzed the results. M.-C.H. contributed to form the structure, organization and presentation of the work. S.-S.H. contributed to generating ideas, designing the experiments, analyzing results, preparing the manuscript, and editing the manuscript.

Funding: This research was funded by the Ministry of Science and Technology, Taiwan, under grant number MOST 107-2637-E-168 -001.

Acknowledgments: We thank H.P. Wang of the Department of Environmental Engineering, National Cheng Kung University, Tainan City, Taiwan for his assistance in the experiments.

Conflicts of Interest: The authors declare no conflict of interest.

\section{References}

1. Noshadi, I.; Richard, N.A.S.; Parnas, S. Continuous production of biodiesel from waste cooking oil in a reactive distillation column catalyzed by solid hetero-polyacid: Optimization using response surface methodology (RSM). Fuel 2012, 94, 156-164. [CrossRef]

2. Schönborn, A.; Ladommatosa, N.; Williams, J.; Allan, R.; Rogerson, J. The influence of molecular structure of fatty acid monoalkyl esters on diesel combustion. Combust. Flame 2009, 156, 1396-1412. [CrossRef]

3. Srilatha, K.; Prabhavathi Devi, B.L.A.; Lingaiah, N.; Prasad, R.B.N.; Sai Prasad, P.S. Biodiesel production from used cooking oil by two-step heterogeneous catalyzed process. Bioresour. Technol. 2012, 119, 306-311. [CrossRef] [PubMed]

4. Ma, F.; Hanna, M. Biodiesel production: A review. Bioresour. Technol. 1999, 70, 1-15. [CrossRef] 
5. Zhang, Y.; Dube, M.A.; McLean, D.D.; Kates, M. Biodiesel production from waste cooking oil: 2. Economic assessment and sensitivity analysis. Bioresour. Technol. 2003, 90, 229-240. [CrossRef]

6. Hass, M.J.; McAloon, A.J.; Yee, W.C.; Foglia, T.A. A process model to estimate biodiesel production costs. Bioresour. Technol. 2006, 97, 671-678. [CrossRef] [PubMed]

7. Kulkarni, M.G.; Dalai, A.K. Waste cooking oil-an economical source for biodiesel: A review. Ind. Eng. Chem. Res. 2006, 45, 2901-2913. [CrossRef]

8. Van Kasteren, J.M.N.; Nisworo, A.P. A process model to estimate the cost of industrial scale biodiesel production from waste cooking oil by supercritical transesterification. Resour. Conserv. Recycl. 2007, 50, 442-458. [CrossRef]

9. Gui, M.M.; Lee, K.T.; Bhatia, S. Feasibility of edible oil vs. non-edible oil vs. waste edible oil as biodiesel feedstock. Energy 2006, 33, 1646-1653. [CrossRef]

10. Tan, K.T.; Lee, K.T.; Mohamed, A.R. Potential of waste palm cooking oil for catalyst-free biodiesel production. Energy 2006, 36, 2085-2088. [CrossRef]

11. Deng, X.; Fang, Z.; Liu, Y.H.; Yu, C.L. Production of biodiesel from Jatropha oil catalyzed by nanosized solid basic catalyst. Energy 2011, 36, 777-784. [CrossRef]

12. Kumaran, P.; Mazlini, N.; Hussein, I.; Nazrain, M.; Khairul, M. Technical feasibility studies for Langkawi WCO (waste cooking oil) derived-biodiesel. Energy 2011, 36, 1386-1393. [CrossRef]

13. Di, Y.; Cheung, C.S.; Huang, Z. Experimental investigation on regulated and unregulated emissions of a diesel engine fueled with ultra-low sulfur diesel fuel blended with biodiesel from waste cooking oil. Sci. Total Environ. 2009, 407, 835-846. [CrossRef] [PubMed]

14. Ozsezen, A.N.; Canakci, M.; Turkcan, A.; Sayin, C. Performance and combustion characteristics of a DI diesel engine fueled with waste palm oil and canola oil methyl esters. Fuel 2009, 88, 629-636. [CrossRef]

15. Chen, P.C.; Wang, W.C.; Roberts, W.L.; Fang, T. Spray and atomization of diesel fuel and its alternatives from a single-hole injector using a common rail fuel injection system. Fuel 2013, 103, 850-861. [CrossRef]

16. Sun, J.; Caton, J.A.; Jacobs, T.J. Oxides of nitrogen emissions from biodiesel-fuelled diesel engines. Prog. Energy Combust. Sci. 2010, 36, 677-695. [CrossRef]

17. Saravanan, S.; Nagarajan, G.; Lakshmi, G.; Rao, N.; Sampath, S. Combustion characteristics of a stationary diesel engine fuelled with a blend of crude rice bran oil methyl ester and diesel. Energy 2010, 35, 94-100. [CrossRef]

18. Tsolakis, A.; Megaritis, A.; Wyszynski, M.L.; Theinnoi, K. Engine performance and emissions of a diesel engine operating on diesel-RME (rapeseed methyl ester) blends with EGR (exhaust gas recirculation). Energy 2007, 32, 2072-2080. [CrossRef]

19. Zheng, M.; Mulenga, M.C.; Reader, G.T.; Wang, M.; Ting, D.S.; Tjong, J. Biodiesel engine performance and emissions in low temperature combustion. Fuel 2008, 87, 714-722. [CrossRef]

20. Kelly, J.F.; Stanciulescu, M.; Charland, J.P. Evaluation of amines for the selective catalytic reduction (SCR) of NOx from diesel engine exhaust. Fuel 2006, 85, 1772-1780. [CrossRef]

21. Hess, M.A.; Haas, M.J.; Foglia, T.A. Attempts to reduce NOx exhaust emissions by using reformulated biodiesel. Fuel Process. Technol. 2007, 88, 693-699. [CrossRef]

22. Muncrief, R.L.; Rooks, C.W.; Cruz, M.; Harold, M.P. Combining biodiesel and exhaust gas recirculation for reduction in NOx and particulate emissions. Energy Fuels 2008, 22, 1285-1296. [CrossRef]

23. Dmytryshyn, S.L.; Dalai, A.K.; Chaudhari, S.T.; Mishra, H.K.; Reaney, M.J. Synthesis and characterization of vegetable oil derived esters: Evaluation for their diesel additive properties. Bioresour. Technol. 2004, 92, 55-64. [CrossRef] [PubMed]

24. Vicente, G.; Martinez, M.; Aracil, J. Integrated biodiesel production: A comparison of different homogeneous catalysts systems. Bioresour. Technol. 2004, 92, 297-305. [CrossRef] [PubMed]

25. Ganesh, L.; Maddikeri, A.; Pandit, B.; Gogate, P.R. Ultrasound assisted interesterification of waste cooking oil and methyl acetate for biodiesel and triacetin production. Fuel Process. Technol. 2013, 116, 241-249.

26. Chen, K.S.; Lin, Y.C.; Hsu, K.H.; Wang, H.K. Improving biodiesel yields from waste cooking oil by using sodium methoxide and a microwave heating system. Fuel 2012, 38, 151-156. [CrossRef]

27. Huppertz, T. Homogenization of Milk Other Types of Homogenizer (High-Speed Mixing, Ultrasonics, Microfluidizers, Membrane Emulsification). Encycl. Dairy Sci. 2011, 761-764. 
28. Håkansson, A.; Trägårdh, C.; Bergenståhl, B. Studying the effects of adsorption, recoalescence and fragmentation in a high pressure homogenizer using a dynamic simulation model. Food Hydrocoll. 2009, 23, 1177-1183. [CrossRef]

29. Joshi, S.; Gogate, P.R.; Moreira, P.F., Jr.; Giudici, R. Intensification of biodiesel production from soybean oil and waste cooking oil in the presence of heterogeneous catalyst using high speed homogenizer. Ultrason. Sonochem. 2017, 39, 645-653. [CrossRef] [PubMed]

30. Mohod, A.V.; Gogate, P.R.; Viel, G.; Firmino, P.; Giudici, R. Intensification of biodiesel production using hydrodynamic cavitation based on high speed homogenizer. Chem. Eng. J. 2017, 31, 751-757. [CrossRef]

31. American Oil Chemists' Society. Acid Value of Fats and Oils. In AOCS Official Method Cd 3d-63; Official Methods and Recommended Practices of the American Oil Chemists' Society: Champaign, IL, USA, 2017.

32. American Oil Chemists' Society. Saponification Value of Fats and Oils. In AOCS Official Method Cd 3d-63; Official Methods and Recommended Practices of the American Oil Chemists' Society: Champaign, IL, USA, 2017.

33. Anastopoulos, G.; Zannikou, Y.; Stournas, S.; Kalligeros, S. Transesterification of vegetable oils with ethanol and characterization of the key fuel properties of ethyl esters. Energies 2009, 2, 362-376. [CrossRef]

34. Kuan, I.; Kao, W.C.; Chen, C.L.; Yu, C.Y. Microbial biodiesel production by direct transesterification of Rhodotorula glutinis biomass. Energies 2018, 11, 1036. [CrossRef]

35. Hsiao, M.C.; Lin, C.C.; Chang, Y.H. Microwave irradiation-assisted transesterification of soybean oil to biodiesel catalyzed by nanopowder calcium oxide. Fuel 2011, 90, 1963-1967. [CrossRef]

36. Hsiao, M.C.; Lin, C.C.; Chang, Y.H.; Chen, L.C. Ultrasonic mixing and closed microwave irradiation-assisted transesterification of soybean oil. Fuel 2010, 89, 3618-3622. [CrossRef]

37. Wang, Y.; Ou, S.; Liu, P.; Xue, F.; Tang, S. Comparison of two different processes to synthesize biodiesel by waste cooking oil. J. Mol. Catal. A Chem. 2006, 252, 107-112. [CrossRef]

38. Canakci, M.; Van Gerpen, J. Biodiesel production from oils and fats with high free fatty acids. Trans. ASAE 2001, 44, 1429-1436. [CrossRef]

39. Freedman, B.; Pryde, E.H.; Mounts, T.L. Variables affecting the yields of fatty esters from transesterified vegetable oils. J. Am. Oil Chem. Soc. 1984, 61, 1638-1643. [CrossRef]

40. Freedman, B.; Butterfield, R.O.; Pryde, E.H. Transesterification kinetics of soybean oil. J. Am. Oil Chem. Soc. 1986, 63, 1375-1380. [CrossRef]

41. Encinar, J.M.; Gonzalez, J.F.; Rodriguez, J.J.; Tejedor, A. Biodiesel fuels from vegetable oils: Transesterification of Cynara cardunculus L. Oils with Ethanol. Energy Fuels 2002, 16, 443-450. [CrossRef] 